\title{
PELATIHAN DAN WORKSHOP DESAIN PEMBELAJARAN BAGI GURU SEKOLAH MENENGAH KEJURUAN (SMK)
}

\author{
Nova Pratiwi ${ }^{1}$, Zahruddin Hodsay $^{2}$, Neta Dian Lestari ${ }^{3}$, Depi Pramika ${ }^{4}$, \\ Hendri Gunawan ${ }^{5}$, Erma Yulaini ${ }^{6}$, Chandra Kurniawan ${ }^{7}$ \\ Program Studi Pendidikan Akuntansi Universitas PGRI Palembang \\ Email : vhapratiwi@gmail.com¹, zhodsay@gmail.com², neta_obyta@yahoo.com³ \\ depi.neynda0506@gmail.com ${ }^{4}$, jayasampurna85@gmail.com ${ }^{5}$, ermayulaini074@gmail.com ${ }^{6}$, \\ chandrakurniawan79@gmail.com?
}

\begin{abstract}
Abstrak
Pengabdian kepada masyarakat ini bertujuan untuk memberikan pelatihan kepada tenaga pengajar di lingkungan sekolah menengah kejuruan (SMK) Negeri 1 Pemulutan Kabupaten Ogan Ilir (OI) mengenai variasi desain pembelajaran, mengingat kedudukan dan peran pentingnya seorang guru sebagai fasilitator pembelajaran bagi peserta didiknya. Desain pembelajaran yang dimaksudkan pada pelatihan ini meliputi manajemen pengelolaan kelas, metode pembelajaran, media pembelajaran, pembelajaran praktik dan ketersediaan sarana prasarana pembelajaran.Pelaksanaan pengabdian kepada masyarakat ini menggunakan beberapa metode yaitu persentasi, diskusi demonstrasi mengajar dan evaluasi. Melalui pelatihan yang diberikan, para peserta mendapatkan referensi tentang berbagai metode pembelajaran kreatif dan menyenangkan yang dapat digunakan dalam pembelajaran akuntansi, serta mendapatkan petunjuk dan arahan tentang penggunaan berbagai benda atau trnasaksi keuangan disekitar peserta didik sebagai media pembelajaran akuntansi yang konkrit. Kesemua hasil yang didapatkan para peserta dari kegiatan pengabdian kepada masyarakat ini tentunya akanmeningkatkan kompetensi guru dalam mengajar akuntansi.
\end{abstract}

\section{Kata Kunci: Pelatihan, Workshop, Desain Pembelajaran, Guru Sekolah Menengah Kejuruan}

\begin{abstract}
This community service aims togive the training to the teachers in the State Vocational Middle School 1 of the Ogan Ilir (OI) Regency regarding the variation of learning designs, given the importance and position of a teacher as a learning facilitator for his students. The learning design intended in this training includes classroom management, learning methods, learning media, practical learning and the availability of learning infrastructure. This community service implementation uses several methods, namely presentation, teaching and evaluation demonstration discussions. Through the training provided, the participants get references on various creative and fun learning methods that can be used in accounting learning, as well as get directions and directions about the use of various objects or financial transactions around students as a concrete accounting learning media. All the results obtained by the participants from the community service activities will certainly increase the teacher's competence in teaching accounting.
\end{abstract}

\section{Keywords: Training, Workshop, Learning Design, Vocational High School Teachers}




\section{Pendahuluan}

Pendidikan adalah salah bentuk perwujudan dari kebudayaan manusia yang dinamis dan sarat perkembangan, oleh karena itu perubahan atau perkembangan pendidikan merupakan hal yang memang seharusnya terjadi seirama dengan perubahan kehidupan manusia (Trianto, 2012:1). Sistem pendidikan yang baik diharapkan mampu melahirkan generasi penerus bangsa yang berkualitas dan mampu menempatkan diri dan mampu bersaing. Melalui penguatan di bidang pendidikan tentunya suatu bangsa dapat mengejar ketertinggalannya dari bangsa lain, baik dalam bidang sains dan teknologi maupun perekonomian.

Pemerintah mencanangkan Indonesia emas di tahun 2045 (disampaikan kementerian PPN dalam orasi ilmiah, UI tahun 2017), yang menjadi target generasi emas di bidang pendidikan antara lain porsi tenaga kerja lulusan pendidikan menengah keatas sebesar 90\% pada tahun 2045. Sasarannya adalah generasi yang saat ini yang sedang mengenyam pendidikan, sehingga ia akan meraih kesuksesan di tahun 2045. Oleh karena itu, pemerintah telah merancang kurikulum 2013 dengan tujuan melahirkan generasi-generasi emas yang responsif dan selektif terhadap kemajuan dan perkembangan zaman. Harapannya 27 tahun yang akan datang Indonesia tidak hanya menjadi pasar tapi juga menjadi pelaku dan pencipta produk yang handal dan mampu bersaing.

Semenjak terlahirnya teori behaviouristik oleh Pavlov, maka sejak itu pula pemahaman bahwa perilaku manusia merupakan sebuah respon, dipengaruhi oleh stimulus yang diberikan oleh lingkungan terus dibuktikan kebenarannya secara ilmiah (Hill, 2012:36). Lingkungan berperan penting dalam perilaku manusia khususnya sekolah, sebab dari sinilah perlakuanperlakuan yang terus menerus diberikan kepada peserta didik, sehingga peserta didik tersebut diharapkan dapat merubah perilakunya sesuai yang diharapkan.

Masa sekolah bukanlah satu-satunya masa bagi peserta didik untuk belajar, diharapkan peserta didik dapat belajar dan berkembang sepanjang hidupnya. Namun disadari bahwa sekolah adalah tempat yang sangat strategis bagi pemerintah dan masyarakat untuk membina generasi muda dalam menghadapi masa depan. Tugas sekolah dalam pendidikan tidak hanya membina pengetahuan dan kecakapan yang berguna untuk dimanfaatkan oleh peserta didik secara langsung setelah lulus, tetapi juga menyiapkan sikap dan nilai, serta kemampuan untuk belajar terus bagi perkembangan pribadinya (Joyce et.,al, 2009:7)

Keberhasilan pembelajaran dalam konteks teori belajar sangat bergantung pada keberhasilan interaksi multiarah, interaksi yang dimaksud adalah interaksi edukasi yang berfungsi untuk mengembangkan berbagai potensi yang dimiliki peserta didik dalam rangka membangun pengetahuan dalam dirinya.Interaksi edukasi ini harus mampu membangun inspirasi, menyenangkan, menantang, memotivasi, serta memberikan ruang yang cukup bagi prakarsa, kreativitas dan kemandirian sesuai bakat, minat dan perkembangan fisik seta psikologis peserta didik (Abidin, 2014:2).

Perubahan paradigma pembelajaran pada kurikulum 2013 seharusnya mendapat respon positif dari berbagai pihak pengelola pendidikan, terutama para tenaga pengajar di sekolah. Pemerintah hanya sekedar memberikan acuan dan bantuan fasilitas, gurulah memegang tombak perubahan sumber daya manusia baru yang 
berkompetensi. Guru harus mampu menciptakan suasana pembelajaran yang kondusif, yang memungkinkan peserta didik berpikir, membangun pengetahuan dan mengembangkan kreativitas. Dengan berbagai pendekatan, metode dan media pembelajaran mutakhir tanpa mengesampingkan penanaman nilai dan norma. Pendidik juga di tuntut mampu mendidik peserta didik menjadi manusia yang selalu mengikuti perkembangan zaman tanpa meninggalkan akar budaya yang sangat penting dalam menentukan perjalanan generasi bangsa, pendidik seharusnya bisa menjebatani kepentingan tersebut dengan menempatkan dirinya berperan sebaikbaiknya dalam pembelajaran (Darmawan, 2012:8).

Menurut UU guru dan dosen no.14 tahun 2005 pasal 1 ayat 1 dinyatakan bahwa "Guru adalah pendidik profesional dengan tugas utama mendidik, mengajar, membimbing, mengarahkan, melatih, menilai dan mengevaluasi peserta didik pada jalur pendidikan formal, pendidikan anak usia dini, pendidikan dasar dan pendidikan menengah. Kinerja guru berkaitan dengan tugas perencanaan, pengelolalan pembelajaran dan penilaian hasil belajar peserta didik. Sebagai perencana, maka guru harus mampu mendesain pembelajaran yang sesuai dengan kondisi di lapangan, sebagai pengelola maka guru harus mampu menciptakan iklim pembelajaran yang kondusif sehingga peserta didik dapat belajar dengan baik, dan sebagai evaluator guru mampu melaksanakan penilaian proses dan hasil belajar peserta didik.

Desain Pembelajaran merupakan kegiatan guru menyusun media komunikasi dan isi agar dapat terjadi transfer pengetahuan secara efektif antara guru dan peserta didik. Proses ini merupakan tolak ukur penentu pemahaman awal peserta didik, merumuskan tujuan pembelajaran jangka panjang dan merancang "perlakuan" dengan bantuan berbagai media sebagai alatbantu terjadinya perubahan. Idealnya proses ini berdasar pada informasi dari teori belajar yang sudah teruji secara pedagogis dan dapat terjadi hanya pada peserta didik, dipandu oleh guru, atau dalam latar berbasis komunitas. Desain pembelajaran juga merupakan proses keseluruhan tentang kebutuhan dan tujuan belajar serta sistem penyampaiannya. Termasuk di dalamnya adalah pengembangan bahan dan kegiatan pembelajaran, uji coba dan penilaian bahan, serta pelaksanaan kegiatan pembelajarannya (Abidin, 2014:53).

Penggunaan media komunikasi yang bervariasi merupakan ketrampilan penting yang harus dimiliki seorang guru dalam pembelajaran dikelas. guru harus pandai memilih dan memilah metode yang tepat agar pembelajaran terus berlangsung menarik dan peserta didik tidak dilanda kejenuhan dalam belajar. Menurut Sukmadinata (2013:191) pemilihan metode yang tepat akan sangat berpengaruh terhadap kualitas pembelajaran. Semakin pandai memilih variasi dalam metode pembelajaran, maka akan semakin besar minat dan perhatian peserta didik dalam mengikuti pembelajaran. Sama halnya pada keterampilan menggunakan variasi metode pembelajaran, media dan sumber belajar sangat penting dalam meningkatkan kualitas pembelajaran. Guru dapat memanfaatkan media dan sumber belajar, mulai dari yang ada disekitar kita, maupun media-media lain yang sesuai dengan materi yang diajarkan.

Undang-Undang Nomor 20 Tahun 2003 tentang Sistem Pendidikan Nasional, Undang-Undang Nomor 14 tahun 2005 tentang Guru dan Dosen dan Peraturan 
Pemerintah Nomor 19 Tahun 2005 tentang Standar Nasional Pendidikan menegaskan bahwa salah satu unsur Tri Dharma Perguruan Tinggi adalah Pengabdian kepada Masyarakat (PkM). Berdasarkan latar belakang tersebut, maka Program Studi Pendidikan Akuntansi FKIP Universitas PGRI Palembang mengadakan kegiatan: Pelatihan dan Workshop Desain Pembelajaran pada Sekolah Menengah Kejuruan Negeri (SMK N) 1 Pemulutan Kabupaten Ogan Ilir (OI) sebagai bentuk pelaksanaan Tri dharma Perguruan Tinggi, berupa Pengabdian kepada Masyarakat (PKM).

Adapun tujuan diadakannya kegiatan pengabdian pada masyarakat ini adalah:

a. Melaksanakan Tri Dharma Perguruan Tinggi

b. Merealisasikan program kerja Program Studi Pendidikan Akuntansi FKIP Universitas PGRI Palembang.

c. memberikan pelatihan kepada tenaga pengajar di lingkungan sekolah menengah kejuruan (SMK) Negeri 1 Pemulutan Kabupaten Ogan Ilir (OI) mengenai desain pembelajaran, mengingat kedudukan dan peran pentingnya seorang guru sebagai fasilitator pembelajaran bagi peserta didiknya.

\section{Bahan dan Metode Pelaksanaan}

Kegiatan pengabdian kepada masyarakat ini dilaksanakan pada pada hari Selasa, 15 Mei 2018 dimulai pukul 08.00 WIB sampai dengan 14.00 WIB, bertempat di aula SMK Negeri 1 Pemulutan Kabupaten Ogan Ilir (OI).Tema pada kegiatan ini adalah "Menjadi Tenaga Pendidik yang Kreatif Mendesain Pembelajaran". Bentuk dari kegiatan Pengabdian kepada Masyarakat ini berupa: persentasi, diskusi, demonstrasi mengajar dan evaluasi.

Narasumber pada kegiatan ini adalah dosen di lingkungan Program Studi Pendidikan Akuntansi Universitas PGRI Palembang yang berjumlah 7 orang. Adapun bahan yang menjadi objek pelatihan pada kegiatan pengabdian kepada masayarakat ini merupakan hasil penelitian yang telah dilakukan oleh masing-masing dosen. Secara rinci materi yang disampaikan dapat dijelaskan melalui tabel berikut ini:

Tabel 2.1 Rincian Pemateri

\begin{tabular}{|c|c|c|}
\hline No & Nama & Judul Materi \\
\hline 1 & $\begin{array}{l}\text { Erma Yulaini } \\
\text { S.Pd., M.Si }\end{array}$ & $\begin{array}{l}\text { Administrasi Sarana } \\
\text { Pendidikan dalam } \\
\text { Meningkatkan Hasil } \\
\text { Belajar Akuntansi }\end{array}$ \\
\hline 2 & $\begin{array}{l}\text { Depi Pramika, } \\
\text { S.Pd., M.Si }\end{array}$ & $\begin{array}{l}\text { Pengaruh Penerapan } \\
\text { Model Pembelajaran } \\
\text { Kooperatif Tipe } \\
\text { Artikulasi Terhadap } \\
\text { hasil Belajar Siswa }\end{array}$ \\
\hline 3 & $\begin{array}{l}\text { Nova Pratiwi, } \\
\text { M.Pd }\end{array}$ & $\begin{array}{l}\text { Meningkatkan Hasil } \\
\text { Belajar Siswa Melalui } \\
\text { Pembelajaran } \\
\text { Pengalaman } \\
\text { (Experiential } \\
\text { Learning) } \\
\end{array}$ \\
\hline 4 & $\begin{array}{l}\text { Chandra } \\
\text { Kurniawan, } \\
\text { S.E., M.Si }\end{array}$ & $\begin{array}{l}\text { Koperasi dan } \\
\text { Kewirausahaan }\end{array}$ \\
\hline 5 & $\begin{array}{l}\text { Zahruddin } \\
\text { Hodsay, S.Pd., } \\
\text { M.M }\end{array}$ & $\begin{array}{l}\text { Pemanfaatan Bukti- } \\
\text { Bukti Transaksi } \\
\text { Rumah Tangga } \\
\text { Sebagai Media } \\
\text { Pembelajaran }\end{array}$ \\
\hline 6 & $\begin{array}{l}\text { Neta Dian } \\
\text { Lestari, S.Pd., } \\
\text { M.M }\end{array}$ & $\begin{array}{l}\text { Limbah Lingkungan } \\
\text { Sebagai Media } \\
\text { Pembelajaran untuk } \\
\text { Menumbuhkan Jiwa } \\
\text { Kewirausahaan }\end{array}$ \\
\hline 7 & $\begin{array}{l}\text { Hendri } \\
\text { Gunawan, } \\
\text { S.Pd., M.Pd }\end{array}$ & $\begin{array}{l}\text { Pengembangan E- } \\
\text { modul Akuntansi }\end{array}$ \\
\hline
\end{tabular}




\section{Hasil dan Pembahasan}

Kegiatan pengabdian kepada masyarakat yang dilakukan di SMK Negeri 1 Pemulutan ini menghasilkan luaran berupa modul dan artikel ilmiah. Modul yang disusun terdiri dari 20 halaman yang mencakup definisi administrasi sarana pendidikan yang baik, perencanaan pembelajaran dengan model kooperatif, perencanaan pembelajaran pengalaman, panduan pemanfaatan media pembelajaran konkrit, pemanfaatan koperasi sekolah sebagai media belajar peserta didikserta panduan mengembangkan modul elektronik bagi guru. Modul tersebut telah dibagikan kepada peserta pelatihan sebagai panduan mengikuti kegiatan pengabdian kepada masyarakat yang dilaksanakan. Selanjutnya kegiatan ini menghasilkan sebuah artikel ilmiah yang telah disusun oleh tim pelaksana berdasarkan laporan akhir hasil kegiatan pengabdian kepada masyarakat, lalu akan diajukan pada pengelola jurnal pengabdian kepada masyarakat yang berISSN.

Modul yang telah disusun tim pelaksana dibagikan kepada peserta pelatihan dan dipersentasikan secara bergantian oleh masing-masing pemateri yang bertanggung jawab, sedangkan artikel ilmiah disusun setelah laporan pengabdian kepada masyarakat selesai dilaksanakan.

Sebelum persentasi oleh pemateri dimulai, pihak sekolah membuka acara dengan dilanjutkan perkenalan sekolah sasaran yaitu SMK Negeri 1 Pemulutan dan perkenalan Universitas PGRI Palembang dan masing-masing pemateri serta mengutarakan maksud dan tujuan kegiatan pengabdian kepada masyarakat sebagai salah satu kegiatan Tri Dharma Perguruan Tinggi.

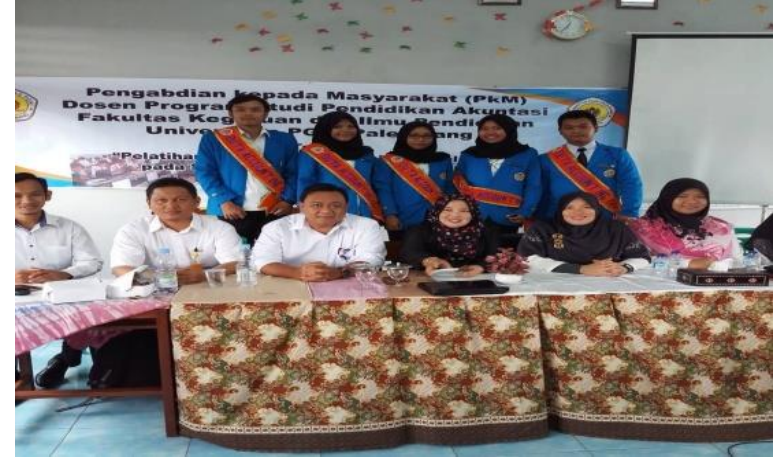

\section{Admistrasi Sarana Pendidikan}

Kegiatan pemaparan oleh tim dosen, dibuka dengan materi dan diskusi tentang administrasi sarana pendidikan. Pemaparan tentang administrasi sarana pendidikan yang meliputi cakupan sarana belajar secara umum, karakteristik peserta didik serta kebutuhan masing-masing peserta didik akan sarana belajar, penataan posisi sarana belajar yang tepat sesuai kebutuhan belajar peserta didik serta peran guru dalam memahamkan peserta didik tentang pemanfaatan dan pemeliharaan sarana belajar untuk kepentingan bersama. Setelah pemaparan dilanjutkan dengan diskusi. Diskusi yang dilakukan bersifat terbuka dan suasana yang akrab, berbagi pengalaman dari tim dosen dan para peserta dalam mengajar dan ketersediaan sarana belajar sebagai pendukung. Pertanyaan meliputi kiat-kiat menyiasati kekurangan sarana belajar, agar pembelajaran tetap berlangsung dengan baik meskipun masih banyak kekurangan fasilitas belajar baik dari sekolah itu sendiri ataupun fasilitas pribadi peserta didik.

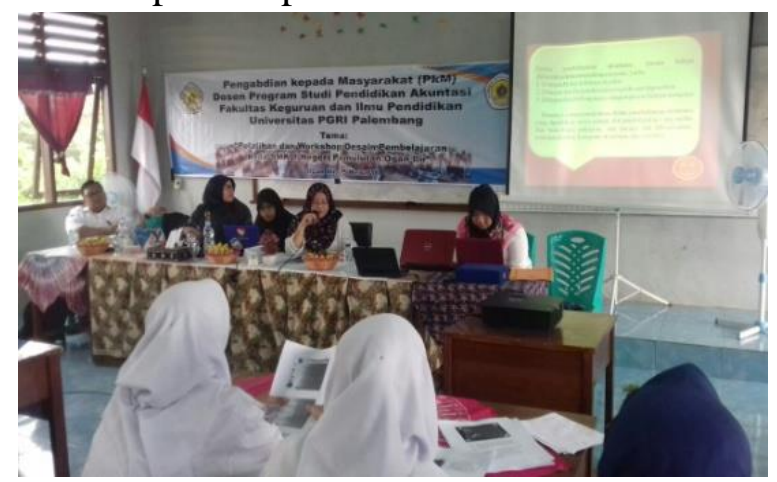




\section{Menerapkan Model Pembelajaran Kooperatif}

Pada hari yang sama dilanjutkan pemaparan kedua oleh tim dosen sebagai pemateri selanjutnya tentang menerapkan model pembelajaran kooperatif sebagai salah satu variasi pembelajaran. Pemaparan tentang Model pembelajaran kooperatif tipe artikulasi meliputi pengertian dan langkahlangkah penerapannya dalam pembelajaran di SMK. Pembelajaran kooperatif tipe artikulasi merupakan sebuah pembelajaran yang menuntut peserta didik berperan aktif, prosesnya seperti pesan berantai, artinya informasi yang telah disampaikan guru kepada salah seorang peserta didik maka ia wajib meneruskan pada peserta didik.

Pemaparan dilanjutkan dengan diskusi seputar penerapan model artikulasi ini dalam pembelajaran. Tim dosen dan peserta pelatihan berbagi pengalaman tentang penerapan beberapa tipe dari model kooperatif dalam pembelajaran.

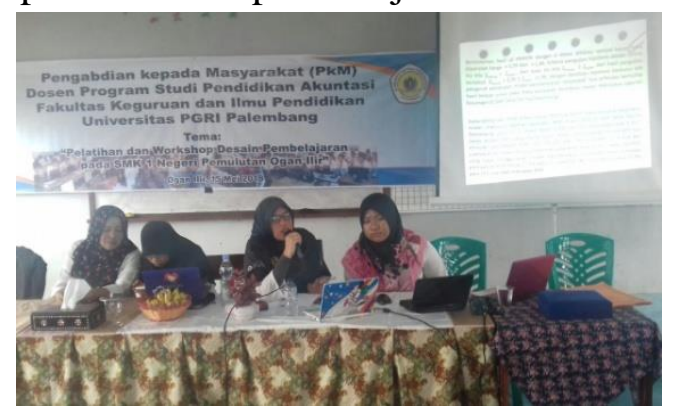

\section{Pembelajaran Pengalaman}

Pemaparan dilanjutkan pada sesi ketiga dengan materi yang cukup menarik perhatian para peserta, berdasarkan penuturan peserta pada saat perkenalan, belajar dari pengalaman adalah sebuah pepatah lama yang sudah mendarah daging dan bukanlah sesuatu yang baru bagi kita semua, namun mereka sangat tertarik mendengarkan lebih jauh tentang bagaiamana jika pepatah lama itu menjadi sebuah cara atau metode mengajar yang dapat digunakan guru dalam menyampaikan konsep pengetahuan di sekolah.

Pembelajaran pengalaman merupakan sebuah model pembelajaran yang pertama kalinya diperkenalkan oleh David Kolb pada tahun 1980-an, pembelajaran ini merupakan suatu proses, dengannya pengetahuan diciptakan melalui transformasi pengalaman. Berbeda dengan pepatah lama yang kita kenal, Kolb berpandangan bahwa pengalaman bukanlah sebuah pengetahuan, melainkan pengalaman merupakan pondasi bagi peserta didik menciptakan pengetahuan.

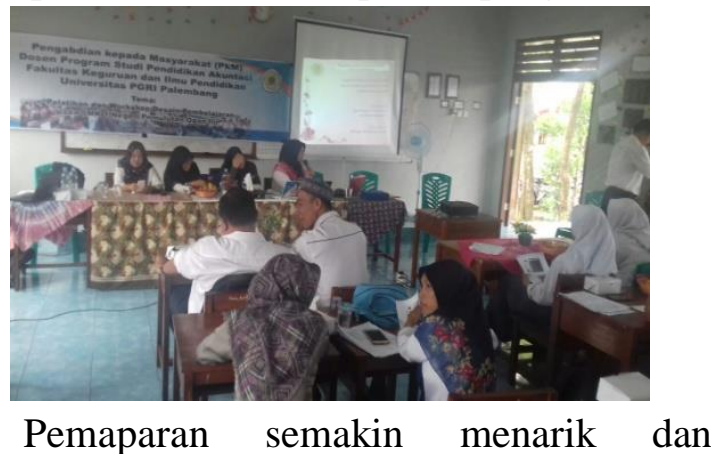
berlanjut pada sebuah demonstrasi singkat, sebagai contoh konkrit dari penerapan pembelajaran pengalaman pada matapelajaran kewirausahaan. Pada mata pelajaran kewirausahaan, guru akan membagi peserta didik dalam kelompok-kelompok kecil, peserta didik dalam kelompok masingmasing diminta untuk membuat prakarya yang dapat dijual pada kegiatan pameran sekolah, maka dari hasil kegiatan tersebut peserta didik diminta untuk membuat runtutan kegiatan yang telah mereka lalui selama merencakanan, membuat dan menjual prakarya mereka. Dari runtutan kegiatan yang telah dibuat guru dapat membantu peserta didik untuk memahami konsep mendirikan dan menjalankan usahakecil sesuai dengan konsep pada buku panduan.

Setelah pemaparan dilanjutkan dengan diskusi yang dilakukan bersifat terbuka dengan suasana yang akrab, tanya jawab seputar tata cara penerapan pembelajaran 
pengalaman pada mata peljaran yang berbeda. Pembelajaran pengalaman bisa diterapkan pada mata pelajaran apapun, jika sesuai dengan kriteria model dan ketersediaan ruang dan waktu untuk melakukan kegiatan praktek pengalaman, pembelajaran pengalaman ini sangat menguntungkan bagi guru dan peserta didik karena akan secara total dan kuat menenggelamkan peserta didik dalam kegiatan mengalami sendiri isu yang tengah dieksplorasi, dan sebagai akibatnya akan mempengaruhi penghayatan karakter, kemampuan kognitif, nilai dan sikap.

\section{Koperasi dan Kewirausahaan}

Materi keempat dilanjutkan setelah istirahat (coffee break) dengan materi koperasi dan kewirausahaan. Pemaparan tentang koperasi dan kewirausahaan yang meliputi cakupan pengertian koperasi secara umum, peluang wirausahaan bagi peserta didik, pemanfaatan koperasi sekolah sebagai ruang untuk peserta didik belajar akuntansi dan wirausaha serta peran guru dalam membina koperasi sekolah.

Setelah pemaparan oleh tim dosen, maka dilanjutkan dengan diskusi terbuka dan suasana yang akrab, berbagi pengalaman dari tim dosen dan para peserta dalam dunia perkoperasian dan kewirausahaan. Sebagian dari peserta pernah memulai usaha namun berakhir dengan ketidakpastian untung ruginya. Bagi pemula dalam berwirausaha hal mutlak yang harus disiapkan adalah mental untuk meraup keuntungan dan kesiapan untuk merugi, maka untuk memperkirakan hal tersebut wirausahawan pemula harus memiliki catatan atau rekam jejak (record) tentang usahanya sejak pertama kali ia dirikan, berapa kisaran modal yang dikeluarkan diawal serta berapa banyak sisa produk pada setiap akhir periode.
Pertanyaan meliputi kiat-kiat memulai usaha kecil dan tata cara pengelolaan koperasi sekolah yang sehat, agar koperasi sekolah dapat dijadikan wadah untuk peserta didik berkarya dan belajar menjadi wirausawan.

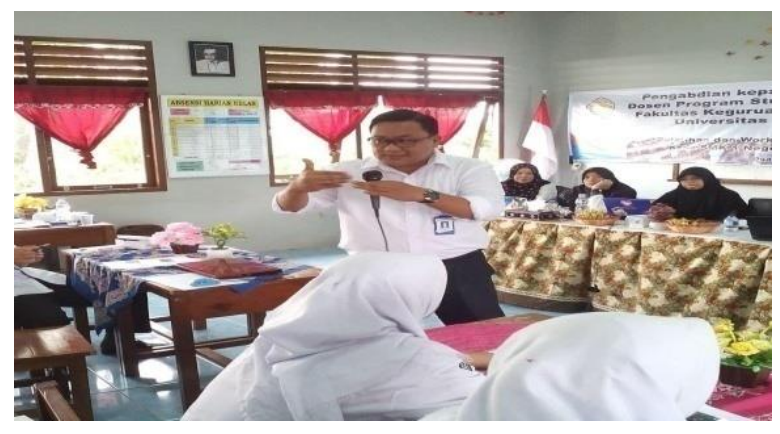

\section{Media Pembelajaran Konkrit}

Pada bahasan tentang media pembelajaran konkrit meliputi pengertian media pembelajaran, macam-macam media pembelajaran, pemanfaatan benda-benda sekitar peserta didik sebagai media pembelajaran. Materi disajikan dua orang, yang pertama yaitu tentang pemanfaatan bukti-bukti transaksi rumah tangga Sebagai Media Pembelajaran akuntansi. Membahas tentang kreativitas seorang guru dalam memanfaatkan bukti-bukti transaksi rumah tangga dalam upaya menyajikan pengalaman belajar pencatatan akuntansi yang bermakna dan mendalam bagi peserta didik.

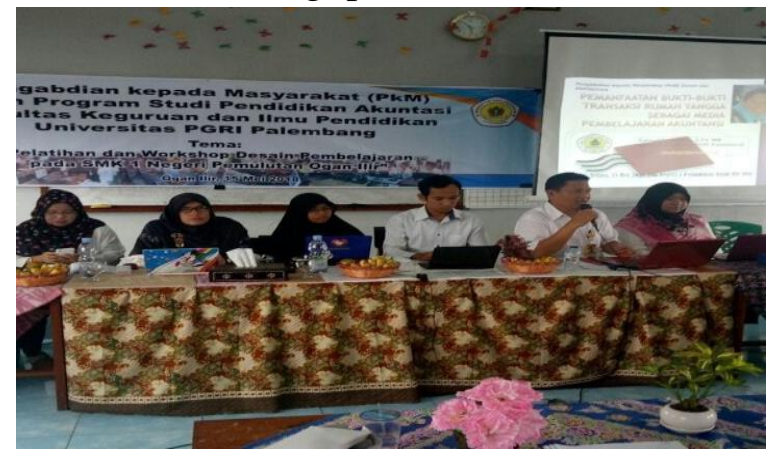

Masih pada topik yang sama, materi selanjutnya membahas tentang Limbah Lingkungan Sebagai Media Pembelajaran untuk Menumbuhkan Jiwa Kewirausahaan. Pemikiran kreatif guru sangat berperan dalam keberlangsungan pembelajaran bermakna. 
Limbah di lingkungan sekitar peserta didik dapat disiasati dengan memanfaatkannya sebagai bahan karya yang bernilai jual, sehingga limbah lingkungan dapat berkurang serta pembelajaran menjadi lebih bervariasi dan menyenangkan bagi peserta didik.

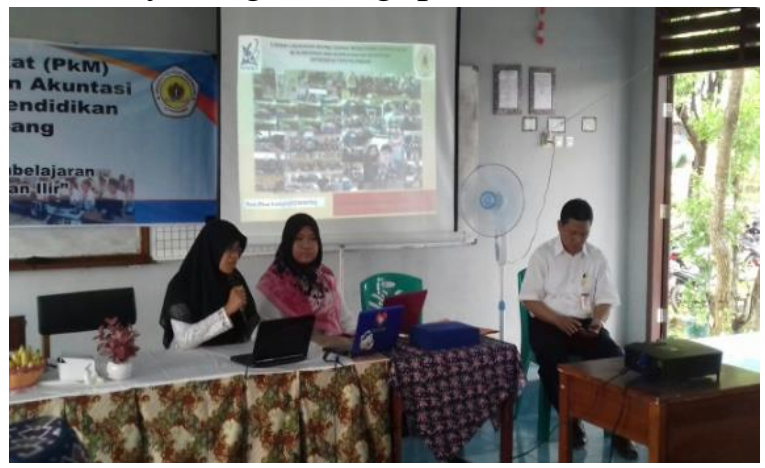

Pemaparan dilanjutkan dengan diskusi terbuka bagi peserta pelatihan dan tim dosen, berbagi pengalaman dari beberapa orang dari tim dosen yang pernah mengambil proyekhibah penelitian daur ulang limbah yang melibatkan mahasiswa dan dosen, hal tersebut disambut antusias oleh para mahasiswa tutur tim dosen.

\section{Pengembangan E-modul Akuntansi}

Pemaparan terakhir oleh tim dosen dengan materi pengembangan E-modul akuntansi. Pada pembelajaran akuntansi di tingkat SMK dimana permasalahan yang timbul timbul yaitu kurang tersedianya sumber belajar mandiri dan jam pelajaran yang kurang pada mata pelajaran akuntansi di sekolah serta penggunaan bahan ajar pembelajaran akuntansi yang bersumber dari penerbit buku ajar akuntansi. Dimana buku ajar dari penerbit lebih memaparkan pelajaran akuntansi secara teoritis atau dapat dikatakan kurangnya penjelasan secara praktis materi ajar ke arah kompetensi pembelajaran terutama pada kompetensi pencatatan transaksi-transaksi akuntansi ke dalam pembukuan-pembukuan akuntansi.

Maka tim dosen menyarankan serta mengajak para peserta untuk menjadi guru yang inovatif, yaitu dengan mengembangkan modul akuntansi berbentuk elektronik. Modul pembelajaran tersebut merupakan salah satu sumber belajar mandiri bagi peserta didik dengan menggunakan fasilitas elektronik seperti leptop dan smart phone berbasis Windows, Android, dan OS, sehingga memungkinkan peserta didik untuk belajar dimanapun dan kapanpun.

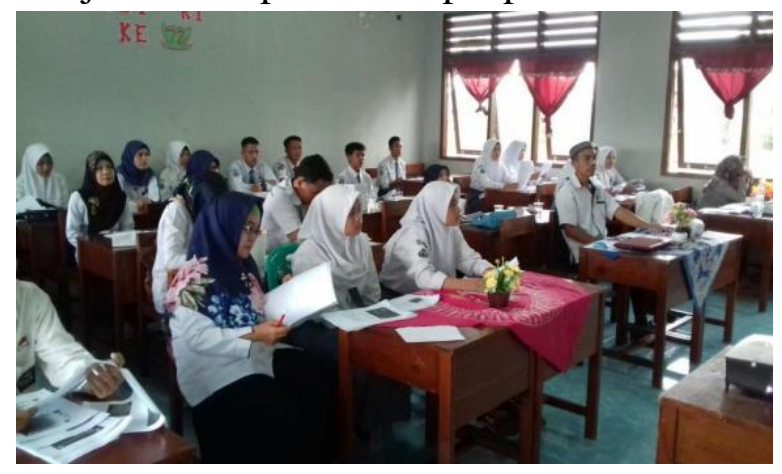

Pemaparan dilanjutkan dengan diskusi, pertanyaan yang diajukan peserta kepada tim pemateri seputar proses pembuatan modul elektronik, Pada tahapan pengembangan pertama peneliti mendisaian bahan ajar di atas kertas, hasil disain berbasis kertas, dibuat dalam bentuk desain berbasis komputerdengan menggunakan program yang peserta kuasai salah satunya yaitu program Adobe Flash. Untuk menguji keabsahan modul yang guru buat maka dapat dilakukan validasi terhadap isi, desain pembelajaran dan media oleh validator lalu diuji cobakan dan direvisi sesuai kebutuhan.

\section{Evaluasi}

Kegiatan diakhiri dengan evaluasi kegiatan, peserta pelatihan pada kegiatan pengabdian kepada masyarakat ini diminta untuk mengisi beberapa pertanyaan seputar materi yang telah disampaikan. Peserta diminta pula untuk menyampikan kritik dan saran terhadap kegiatan yang telah dilaksanakan sebagai bahan kajian dan perbaikan diri bagi tim dosen. Dari hasil evaluasi tampak bahwa kegiatan pengabdian 
kepada masyarakat ini cukup diminati dan telah dipahami dengan baik oleh para peserta, dan tim dosen berharap jika ilmu yang telah dibagi dapat bermanfaat pada kegiatan pembelajaran di SMK Negeri 1 Pemulutan Kabupaten Ogan Ilir (OI).

\section{Simpulan}

Secara keseluruhan tujuan pelaksanaan kegiatan pengabdian kepada masyarakat ini telah tercapai. Telah terlaksananya tugas pokok Tri Dharma Perguruan Tinggi, merealisasikan program kerja program studi dan yang terpenting ialah telah diberikannya pelatihan mendesain pembelajaran bagi guru SMK Negeri 1 Pemulutan, karena mampu mendesain pembelajaran merupakan satu keharusan bagi guru sebagai fasilitator pembelajaran, artinya gurulah yang harus menciptakan kondisi dan susana belajar kondusif sesuai dengan kebutuhan belajar peserta didiknya.

\section{Daftar Pustaka}

Abidin, Yunus. (2014). Desain Sistem Pembelajaran dalam Konteks Kurikulum 2013. Bandung: PT Refika Aditama.

Bahan Paparan Menteri Perencanaan Pembangunan Nasional. (2017). Visi Indonesia 2045. Disampaikan di Jakarta pada Orasi Ilmiah Fakultas Ekonomi dan Bisnis. Universitas Indonesia.

Darmawan, Deni. (2012). Teknologi Pembelajaran. Bandung: Remaja Rosdakarya.

Hill, F., Winfred. (2012). Theories of Learning. Edisi Terjemahan Khozim. Bandung: Nusa Media.

Joyce, Bruce., et., al. (2009). Models of Teaching. Edisi Terjemahan Fawaid, Achmad. Yogyakarta: Pustaka Pelajar.

Sukmadinata, S., Nana. (2013). Pengembangan Kurikulum, Teori dan Praktek. Bandung: Remaja Rosdakarya.

Trianto. (2012). Mendesain Model Pembelajaran Inovatif-Progresif. Jakarta: Prenada Media Group. 